\title{
INTERNALISASI KARAKTER KEMANDIRIAN MELALUI PEMBELAJARAN KONSTRUKTIF DI PERGURUAN TINGGI
}

\author{
RIANAWATI \\ Penulis adalah Dosen IAIN Pontianak
}

\begin{abstract}
Students are young generation, the nation's hope to build a better country. As a young generation, students must have a strong character, independent, responsible, critical, logical, creative, and innovative. Through constructive learning, students are expected to be able to independently improve and use the knowledge to assess and analyze, solve problems, think actively, critically and logically, and take the meaning of what is learned. Therefore, the learning process is student -oriented activities. Constructive learning is not only concerned with the cognitive aspects, but also oriented to the development of skills and noble character of the student. Lecturer facilitates a democratic learning that allows students to develop independent learning. Lecturer served as a facilitator, mentor and director, and evaluator of learning.
\end{abstract}

Keywords: Character, Self, Learning, Konsruktif, Lecturer

\section{LATAR BELAKANG}

Problem moral yang meland dikalangan mahasiswa dewasa ini cukup memprihatinkan. Hal itu antara lain ditandai dengan merosotnya perilaku moral, seperti etika berpakaian, etika pergaulan (rasa hormat kepada karyawan, dosen, dan pimpinan jurusan, fakultas, atau universitas), dan perilaku mahasiswa di ruang kelas, di lingkungan kampus, maupun di luar kampus. Problem moral tersebut tentu tidak bisa dilepaskan dari proses pendidikan dan pembelajaran yang selama ini berlangsung di negara kita, yaitu pendidikan dan pembelajaran yang cenderung kognitif-intelektualistik dan formalistik. Rendahnya karakter bangsa ini menjadi perhatian penting kita semua.

Banyak faktor yang menyebabkan kepribadian atau karakter mahasiswa memburuk. Hal ini dapat dilihat dari prilaku atau etika mahasiswa dalam belajar; mudah putus asa jika belum bisa, tidak jujur dalam belajar. Kurang dapat menghargai pendapat teman, kurang demokratis, tidak disiplin dalam belajar, tidak mandiri dalam belajar, dan juga kurang kreatif. Pada pembelajaran akhlak misalnya, mahasiswa kurang biasa menunjukkan prilaku yang kontraproduktif dalam persoalan-persoalan akhlak. Mereka membaca tetapi tidak memahami makna dari suatu pertanyaan, tidak mencerna informasi yang diperoleh, tidak yakin dengan cara yang digunakan untuk menyelesaikan soal, dan cepat menyerah ketika tidak tahu bagaimana menyelesaikan soal tersebut. Dari kesehari-harian prilaku atau etika mahasiswa di kelas yang demikian berakibat lunturnya/ memburuknya karakter mahasiswa.

Berdasakan hasil pengamatan dan pengalaman selama ini, mahasiswa kurang 
terbuka apabila mengalami kesulitan dalam belajar baik kepada dosen, teman maupun orang lain. Terutama terhadap mahasiswa yang mempunyai kemampuan di bawah rata-rata. Mereka takut bertanya meskipun sudah dipancing dengan pertanyaanpertanyaan yang merangsang daya fikir mereka. Mahasiswa cenderung malas belajar, cepat menyerah atau putus asa. Hal ini tampakdari kuis atau tugas yang diberikan dosen yang hasilnya tidak memuaskan bahkan kadang tidak dapat diselesaikan. Mahasiswa kurang aktif dalam kegiatan pembelajaran, mahasiswa tampak bingung, acuh tak acuh, bahkan ada sebagian mahasiswa yang sama sekali tidak memperhatikan penjelasan dari dosen atau teman, cepat putus asa pada saat dosen membimbing skripsi. Hal yang demikian ini menunjukkan lunturnya atau memburuknya karakter atau kepribadian mahasiswa. Memburuknya karakter tersebut implikasinya pada martabat bangsa Indonesia yang dinilai rendah oleh bangsa lain

Salah satu penyebab lainnya dari persoalan-persoalan yang dialami mahasiswa adalah mahasiswa kurang memiliki karakter mandiri dalam belajar. Akhlak pada diri sendiri yaitu yaitu akhlak yang memberikan kebebasan pada siswa untuk menemukan, membangun, melakukan analisis, kritik, dan kesimpulan dengan pola berpikir logis dan akhlak lainnya seperti, percaya diri, jujur, disiplin, kreatif, optimis, tolong menolong, menghargai, ketekunan, ulet, dan kerja keras. Bila mahasiswa kurang mandiri dalam belajar dan terus bergantung dengan materi yang disampaikan oleh dosen, maka mahasiswa tersebut dapat dipastikan sebagai mahasiswa yang tidak produktif, kreatif, dan inovatif. Banyak waktu akan terbuang sia-sia dan dihabiskan pada halhal yang sia-sia. (menjurus kepada akhlak tercela). Mahasiswa yang kurang mandiri dalam belajar akan memiliki sikap ketergantungan yang sangat kuat pada orang lain, sehingga akan menimbulkan sikap malas dalam belajar, sering membolos, mencontek (karena dia tidak percaya pada kemampuan dirinya sendiri) dan banyak kepribadian yang kurang baik yang akan bermunculan pada mahasiswa yang tidak mandiri dalam belajar.

Sehubungan dengan kemandirian, Ali M. dan Asrori M., ${ }^{1}$ memprediksikan bahwa situasi kehidupan yang tidak mengarah pada kemandirian dapat menyebabkan manusia menjadi serba bingung atau larut ke dalam situasi baru tanpa dapat menyeleksi lagi jika tidak memiliki ketahanan hidup yang memadai.

Oleh karena itu peran institusi perguruan tinggi khususnya Pendidikan Agama Islam bisa merevitalisasi pendidikan dengan mengembangkan karakter mahasiswa melalui pembelajaran. Kebanyakan lembaga pendidikan pada saat ini justru melaksanakan pembelajaran hanya memaksimalkan institusi ilmunya saja, tanpa memperhatikan nilai-nilai karakter mahasiswa yang akibatnya mahasiswa kehilangan jati diri sebagai manusia yang religius dan bermoral.

World Declaration on Higher Education of the Twenty-First Century; Vision and Action, oleh UNESCO ditegaskan bahwa visi dan nilai pokok sebuah Perguruan Tinggi adalah memberikan kontribusi kepada pembangunan yang berkelanjutan dan pengembangan masyarakat secara keseluruhan. Dalam konteks itu maka salah satu visi dan fungsi perguruan tinggi adalah mendidik mahasiswa untuk memenuhi kebutuhan seluruh sektor aktivitas manusia, menanamkan profesionalisme dan kepribadian melalui kombinasi ilmu pengetahuan dengan mata kuliah-mata kuliah yang terus dievaluasi dan terus dikembangkan, untuk menjawab berbagai kebutuhan masyarakat dewasa ini dan masa

\footnotetext{
1 Ali, Muhammad \& Muhammad, Asrori, (2004). Psikologi Remaja (Perkembangan Peserta Didik). Jakarta : Bumi Aksara, h. 78
} 
datang. Oleh karena itu sebuah institusi harus bisa dapat mempersiapkan kualitas SDM yang menguasai IPTEK serta nilainilai modernitas yang dilandasi nilai-nilai moral spiritual agar terbentuknya manusia yang bermoral, memiliki karakter, dan religious.

Dalam konteks Pendidikan Agama Islam, sudah saatnya kita merubah paradigma pengajaran yang selama ini lazim digunakan dalam proses belajar mengajar PAI ke arah paradigma pembelajaran yang demokratis. Bukan rahasia lagi bahwa paradigma belajar mengajar PAI kita selama ini masih sarat orientasi pengajaran ketimbang pembelajarannya. Akibatnya dikalangan mahasiswa, PAI seringkali dipandang sebagai mata kuliah yang menjemukan, sarat dengan dogma dan indoktrinasi norma-norma agama yang kurang membuka ruang bagi mahasiswa untuk lebih kritis dan kreatif dalam proses belajar mengajar. Tidak mengherankan jika kemudian mahasiswa menjadi malas dan kurang bersemangat mengikuti mata kuliah ini.

Anita Lie 2 hasil studi Xaviery menyimpulkan sekurang-kurangnya terdapat tiga masalah pokok yang melatarbelakangi keengganan peserta didik mempelajari suatu mata pelajaran. Pertama, masalah teknik pembelajaran yang tidak menumbuhkan motivasi siswa. Kedua, eksistensi guru bukan sebagai fasilitator yang membelajarkan siswa, melainkan pribadi yang belajar atau menggurui siswa. Ketiga, penyampaian pesan pembelajaran dengan media yang kurang interaktif dan atraktif

Dengan demikian, salah satu model pembelajaran yang dapat membiasakan mahasiswa mandiri dalam belajar adalah model pembelajaran konstruktif. Model pembelajaran konstruktif yaitu model pembelajaran yang mengembangkan dan

\footnotetext{
2 Anita Lie., Cooperative Learning (mempraktekkan Cooperative Learning di Ruang-RuangKelas). Jakarta : Grasindo, h.2
}

meningkatkan kemampuan dan keterampilan secara mandiri dan mahasiswa yang aktif akan menemukan sesuatu dan membangun sendiri pengetahuan dengan cara berdiskusi, mahasiswa mempunyai cara berfikir masing-masing yang kadang mungkin sangat berbeda dari temannya. ${ }^{3}$

Melalui model pembelajaran kontruktif diharapkan akan membangun sumber daya manusia yang memiliki kepekaan, kemandirian, tanggung jawab terhadap resiko dalam pengambilan keputusan, mengembangkan segenap aspek potensi melalui proses belajar yang terus menerus menemukan jati diri mereka sendiri. Melalui model belajar konstruktif, dapat mengantisipasi pergeseran dari pendidikan yang lebih menekankan aspek kognitif menuju aspek potensi manusia secara utuh. Di samping itu teori belajar konstruktif, pembelajarannya lebih menekankan aktivitas mahasiswa dari pada pendidik. Menurut pandangan konstruktivisme belajar merupakan suatu proses pembentukan pengetahuan. Pembentukan ini harus dilakukan individu yang belajar, ia harus aktif melakukan kegiatan, aktif berfikir, menyusun konsep dan memberi makna tentang hal-hal yang dipelajari. Dosen memang dapat dan harus mengambil peran untuk mengarahkan mahasiswa, namun akhirnya yang paling menentukan terwujudnya gejala belajar adalah niat belajar mahasiswa itu sendiri. Konstruktif memandang mahasiswa sebagai pribadi yang memiliki kemampuan awal sebelum mempelajari suatu pengetahuan yang baru. Penilaian terhadap proses belajar mahasiswa merupakan bagian integral dalam pembelajaran, dilakukan melalui observasi dosen terhadap hasil kerja mahasiswa.

Berdasarkan latar belakang di atas, maka penulis tertarik untuk membahas "Implementasi Pembelajaran Konstruktif Dalam Membentuk Karakter Mandiri Pada

3 Qowaid, dkk., (2007). Inovasi Pembelajaran PAI, Jakarta: Pena Citrasatria, h. 7 
Mahasiswa di Perguruan Tinggi." Dalam tulisan ini, penulis ini ingin mengangkat masalah "Apa saja yang merupakan karakter mandiri belajar mahasiswa dan bagaimana mengembangkan karakter kemandirian belajar mahasiswa melalui pembelajaran konstruktif? Tujuan penulisan adalah untuk mengetahui, menganalisis, mengindentifikasi, mengembangkan, dan mendiskripsikan karakter kemandirian belajar mahasiswa dan pengembangan karakter kemandirian belajar mahasiswa melalui pembelajaran konstruktif di Perguruan Tinggi.

\section{PENGERTIAN DAN TUJUAN PENDIDIKAN KARAKTER}

\section{Pengertian Karakter}

Istilah karakter adalah istilah yang baru digunakan dalam wacana Indonesia dalam lima tahun terakhir ini. Istilah ini sering dihubungkan dengan istilah akhlak, etika, moral, atau nilai. Karakter juga sering dikaitkan dengan masalah kepribadian, atau paling tidak ada hubungan yang cukup erat antara karakter dengan kepribadian seseorang. Secara etimologis, kata karakter (Inggris: character) berasal dari bahasa Yunani (Greek), yaitu charassein yang berarti "to engrave". Kata "to engrave" bisa diterjemahkan mengukir, melukis, atau menggoreskan. ${ }^{4}$

Orang berkarakter berarti orang yang berkepribadian, berperilaku, bersifat, bertabiat, atau berwatak. Dengan demikian, karakter merupakan watak dan sifat-sifat seseorang yang menjadi dasar untuk membedakan seseorang dari yang lainnya. Dengan makna seperti itu karakter identik dengan kepribadian atau akhlak. Kepribadian merupakan ciri, karakteristik, atau sifat khas diri seseorang yang bersumber dari bentukanbentukan yang diterima dari lingkungan,

\footnotetext{
4 Echlos, John M. dan Hasan Shadily. (2003.) AnEnglish-Indonesian Dictionary, Jakarta: PT. Gramedia Pustaka Utama, h. 214
}

misalnya keluarga pada masa kecil dan bawaan sejak lahir. ${ }^{5}$

Secara terminologis, makna karakter dikemukakan oleh Thomas Lickona yang mendefiisikan karakter sebagai "A reliable inner disposition to respond to situations in a morally good way." Selanjutnya, Lickona menambahkan, "Character so conceived has three interrelated parts: moral knowing, moral feeling, and moral behavior" 6 . Karakter mulia (good character), dalam pandangan Lickona, meliputi pengetahuan tentang kebaikan (moral khowing), lalu menimbulkan komitmen (niat) terhadap kebaikan (moral feeling), dan akhirnya benar-benar melakukan kebaikan (moral behavior). Dengan kata lain, karakter mengacu kepada serangkaian pengetahuan (cognitives), sikap (attitudes), dan motivasi (motivations), serta perilaku (behaviors) dan keterampilan (skills).

Dari penjelasan di atas dapat dipahami bahwa karakter identik dengan akhlak, sehingga karakter merupakan nilai-nilai perilaku manusia yang universal yang meliputi seluruh aktivitas manusia, baik dalam rangka berhubungan dengan Tuhan, dengan diri sendiri, dengan sesama manusia, maupun dengan lingkungan, yang terwujud dalam pikiran, sikap, perasaan, perkataan, dan perbuatan berdasarkan norma-norma agama, hukum, tata karma, budaya, dan adat istiadat.

\section{Pengertian Pendidikan Karakter}

Pendidikan karakter menurut Creasy ${ }^{7}$ menjelaskan bahwa yang dimaksud dengan pendidikan karakter adalah upaya mendorong peserta didik tumbuh dan berkembang dengan kompetensi berpikir dan berpegang teguh pada prinsip-prinsip moral dalam hidupnya serta mempunyai keberanian untuk

\footnotetext{
${ }^{5}$ Koesoema, Doni, (2007). Pendidikan Karakter, Strategi Mendidik Anak di Zaman Global, Jakarta: PT. Gramedia Widiasarana Indonesia, h. 80

${ }^{6}$ Lickona, T. (1991). Education for character:How our schools can teach respect and responsibility. New York: Bantam Books, h. 51

${ }^{7}$ Zubaidi, op.cit, 2011, h. 16
} 
melakukan yang benar meskipun dihadapkan pada berbagai tantangan.

Berdasarkan pengertian di atas, jelaslah bahwa pendidikan karakter adalah usaha yang di

lakukan oleh pendidik untuk menanamkan nilai-nilai karakter mulia pada peserta didik. Pendidikan karakter, mengandung tiga unsur pokok, yaitu mengetahui kebaikan (knowing the good), mencintai kebaikan (desiring the good), dan melakukan kebaikan (doing the good) ${ }^{8}$. Jadi, pendidikan karakter harus menjadi gerakan nasional yang menjadikan sekolah (institusi pendidikan) sebagai agen untuk membangun karakter peserta didik melalui pembelajaran dan pemodelan. Melalui pendidikan karakter Perguruan Tinggi khususnya harus berpretensi untuk membawa peserta didik memiliki nilai-nilai karakter mulia seperti hormat dan peduli pada orang lain, tanggung jawab, jujur, memiliki integritas, dan disiplin. Di sisi lain pendidikan karakter juga harus mampu menjauhkan peserta didik dari sikap dan perilaku yang tercela dan dilarang. Pendidikan karakter tidak hanya mengajarkan mana yang benar dan mana yang salah kepada mahasiswa, tetapi lebih dari itu pendidikan karakter menanamkan kebiasaan (habituation) tentang yang baik sehingga peserta didik paham, mampu merasakan, dan mau melakukan yang baik. Dengan demikian, pendidikan karakter membawa misi yang sama dengan pendidikan akhlak atau pendidikan moral

\section{Tujuan Pendidikan Karakter}

Pendidikan nilai dalam proses sesungguhnya berupaya membentuk nilainilai pada mahasiswa yang tercermin dalam prilaku sehari-hari baik di perguruan tinggi maupun di lingkungan luar perguruan tinggi. Dalam pelaksanaannya dilakukan dengan bimbingan yang intensif dan konsisten agar diperoleh hasil yang maksimal. Asia and the Pasifik Programe of Educational Indonesia for Development

\footnotetext{
${ }^{8}$ Lickona, Ibid. h.51
}

(APEID) dalam Mulyana ${ }^{9}$ dijelaskan bahwa pendidikan nilai secara khusus ditujukan untuk (1) menerapkan pembentukan nilai pada anak (2) menghasilkan sikap yang mencerminkan nilai-nilai yang diinginkan dan (3) membimbing prilaku yang konsisten dengan nilai-nilai tersebut.

Selanjutnya pendidikan karakter pada intinya membentuk bangsa yang kompetitif, tangguh, berakhlak mulia, bermoral, bertoleran, bergotong royong, berjiwa patriot$\mathrm{ik}$, berjiwa dinamis, berorientasi pada ilmu pengetahuan dan teknologi yang berlandaskan pada Iman dan Takwa Kepada Allah Swt. ${ }^{10}$

Pendidikan karakter juga bertujuan meningkatkan mutu penyelenggara dan hasil pendidikan yang mengarah pada pencapaian pembentukkan karakter dan akhlak mulia secara utuh, terpadu, dan seimbang sesuai dengan norma dan nilai yang ada. Melalui pendidikan karakter diharapkan peserta didik secara mandiri meningkatkan dan menggunakan pengetahuannya, mengkaji, dan menginternalisasi nilai-nilai karakter dan akhlak mulia sehingga terwujud dalam perilaku sehari-hari. ${ }^{11}$

Dengan demikian pendidikan karakter bertujuan menanamkan dan membiasakan peserta didik dengan karakter mulia, sehingga peserta didik dapat mengetahui, memahami, menganalisis, dan menerapkan karakter mulia secara utuh dan terpadu dalam kehidupannya sehari-hari.

\section{Pengertian Mandiri dan \\ Kemandirian Belajar \\ 1. Pengertian Mandiri}

Seseorang yang menjalani kehidupan ini tidak pernah lepas dari cobaan dan tantangan. Individu yang memiliki

\footnotetext{
9 Mulyana, R, 2004, Mengartikulasikan Pendidikan Nilai, Bandung: Alpabeta, h.120

${ }^{10}$ Narwanti, (2011). Pendidikan Karakter Pengintegrasian 18 Nilai Dalam Mata Pelajaran, Yogyakata: Familia, h.16

${ }^{11}$ Narwanti, Ibid., 17
} 
kemandirian tinggi relatif mampu menghadapi segala permasalahan karena individu yang mandiri tidak tergantung pada orang lain, selalu berusaha menghadapi dan memecahkan masalah yang ada. Kemandirian sering juga disebut otonomi. Istilah otonomi sering digunakan untuk merujuk kepada seperangkat masalah psikososial yang penting khususnya selama masa remaja.

Poerwadarminta 12 menyebutkan pengertian kemandirian dalam kamus besar bahasa Indonesia disebutkan bahwa kemandirian adalah keadaan dapat berdiri sendiri, keadaan dapat mengurus atau mengatasi kepentingan sendiri tanpa tergantung kepada orang lain. Sedangkan autonomy atau otonomi adalah kebebasan atau kemampuan untuk bertindak menurut prioritas-prioritas atau prinsip-prinsip sendiri, tanpa dibingungkan oleh paksaanpaksaan dari luar atau tekanan-tekanan dari dalam seperti hasrat-hasrat yang tidak diinginkan tetapi tidak terkuasai. ${ }^{13}$

Berdasarkan pendapat di atas, otonom adalah mengatur diri sendiri atau untuk memutuskan cara sendiri. Hidup mandiri adalah hidup sesuai dengan keinginan dasar seseorang atau nilai-nilai. Dengan dasar keinginan yang diinginkannya demi dirinya sendiri.

Selanjutnya, Steinberg 14 , menjelaskan tentang kemandirian, yaitu :

12 Poerwadarminta, W.J.S. (1976). Kamus Umum Bahasa Indonesia, Jakarta: Balai Pustaka, h. 513

Asihwardji, Danuyasa, (Edt.), (1996). EnsiklopediPsikologi (Pembahasan dan Evaluasi Lengkap Berbagai Topik, Teori, Riset, dan Penemuan Baru Dalam Ilmu Psikologi), Terjemahan Ediati Kamil, Jakarta: Arcan, h. 27

14 Russel, Stephen \& Rosalie J. Bakken, (2002). Development of Autonomy in Adolescence. University of Nebraska: NebGuide, G1449 (http://extension.unl.edu/publications)
"Autonomy refers to an adolescent's growing ability to think, feel, make dicision and act on her or his own. The development of autonomy does not end after the teen years. Throughout adulthood, autonomy continues to develop whenever someone is challenged to act with a new level of self-reliance. Autonomy has special meaning during the preteen and teen years because it signifies that an adolescent is a unique, capable, independent person who depends less on parents and other adults".

Kemandirian mengacu pada kemampuan seorang remaja yang tumbuh untuk berfikir, Pengembangan kemandirian tidak berakhir setelah remaja. Sepanjang usia dewasa, kemandirian terus berkembang. Setiap saat seseorang dihadapkan untuk bertindak dengan tingkat kemandirian yang baru.

Selanjutnya menurut Masrun, dkk ${ }^{15}$, kemandirian adalah suatu sikap yang memungkinkan sesorang berbuat bebas melakukan sesuatu atas dorongan diri sendiri untuk kebutuhan sendiri, mengejar prestasi, penuh ketekunan, serta berkeinginan untuk melakukan sesuatu tanpa bantuan orang lain, mampu berfikir dan bertindak kreatif dan penuh inisiatif, mampu mempengaruhi lingkungannya, mempunyai rasa percaya diri terhadap kemampuan diri sendiri, menghargai keadaan diri sendiri dan memperoleh keputusan dari usahanya.

Dengan demkian, kemandirian pada remaja secara psikologis dianggap penting, karena setiap remaja berusaha menyesuaikan diri secara aktif terhadap lingkungannya. Kemandirian pada remaja dan dewasa awal berbeda dengan

15 Masrun, (1988). Studi Tentang Kemandirian Sebagai Kualitas Kemandirian, Makalah Seminar Ilmu-Ilmu Sosial: Mempersiapkan Masyarakat Masa Depan di Ujung Pandang, h. 13 
kemandirian pada masa anak. Kemandirian pada masa anak lebih mengarah kepada kemandirian secara fisik, sedangkan pada masa remaja lebih mengarah kepada kemandirian psikologis, sedangkan pada" masa dewasa awal kemandirian mengarah kepada kemampuan untuk mandiri secara financial".

\section{Kemandirian Siswa Dalam Belajar}

Makna kemandirian dapat dilihat dari sudut pandang konsep pembelajaran mandiri. Bentuk kemandirian itu adalah kemandirian dalam hal belajar. Menurut Candy 16, kemandirian belajar memilki empat dimensi, yaitu 1) otonomi pribadi (personal outonomy); 2) manajemen diri dalam belajar (self management in learning); 3) meraih kebebasan dalam belajar (the independcent pursuit of learning) 4) kendala/penguasaan pembelajar terhadap pembelajaran (learner control of instrunction) hhtp ://aristorahadi.wordpress.com/2008/03/31 kemandiri an-belajar-siswa-smp.terbuka.

a. Dimensi otonomi pribadi menunjukkan karekteristik individual dari orang yang mampu belajar mandiri. Orang yang memiliki kemandirian adalah orang yang bebas dari tekanan baik internal maupun eksternal, memiliki sekumpulan nilai-nilai dan kepercayaan pribadi yang memberikan konsistensi dalam kehidupannya. Hal ini berarti orang tersebut mampu membuat rencana dan tujuan hidup, bebas dalam membuat pilihan, menggunakan kapasitas dirinya untuk refleksi secara rasional, mempunyai kekuatan kemauan, berdisiplin dan melihat dirinya sendiri sebagai orang yang mandiri.

b. Dimensi manager diri menjelaskan adanya kemauan dan kapasitas dalam diri seseorang untuk mengelola dirinya.

16 Candy, Philip C. (1975), Independent Learning : some Ideas from Literature" San Fransisco : Jossey-Bass Inc, Publishers.
Kapasitas tersebut ditunjukkan dengan adanya keterampilan dan kompetensi dalam diri orang mandiri.

c. Dimensi meraih kebebasan dalam belajar, menggambarkan tentang adanya kebutuhan individu untuk memperoleh kesempatan belajar. Dimensi ini menjelaskan bahwa orang dewasa memiliki kebutuhan untuk meningkatkan diri melalui belajar berbagai hal dalam kehidupan.Dimensi control pembelajar terhadap pembelajaran, menjelaskan tentang peran siswa pada situasi belajar formal yang melibatkan cara mengorganisasi tujuan pembelajaran.

Kegiatan belajar mandiri sebagaimana yang dijelaskan oleh Candy, dapat dilihat dalam Diagram di bawah in

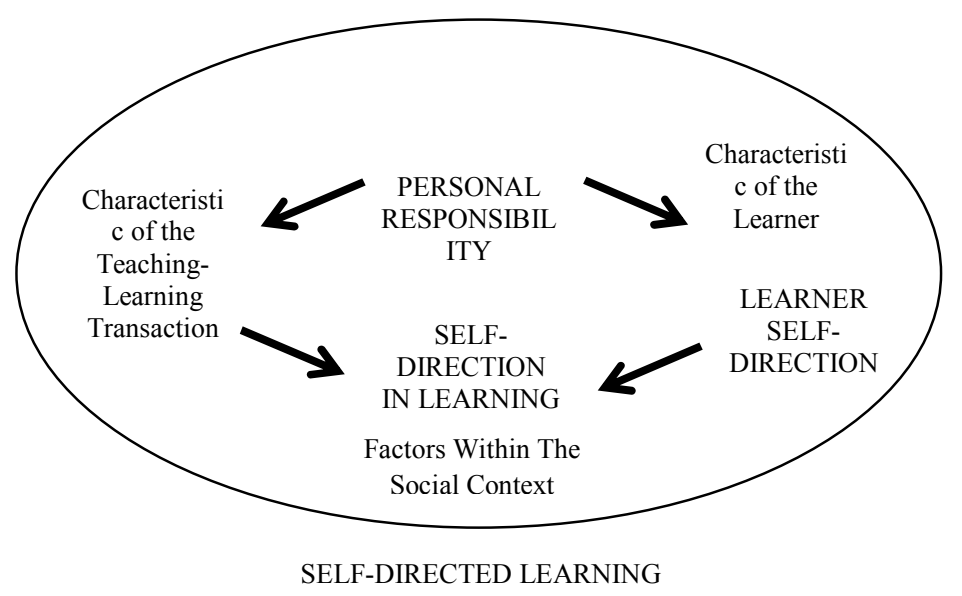

Gambar 2.1 Belajar Mandiri

Belajar mandiri (self-directed learning) yang ada di sisi sebelah kiri dari model, mengacu pada karekteristik proses, atau apa yang kita kenal sebagai faktor eksternal dari siswa/mahasiswa. Di sini mengacu pada bagaimana proses pembelajaran itu dilaksanakan. Mahasiswa/siswa mandiri (learner seldirection) yang ada di sebelah kanan model, mengacu pada individu yang melakukan kegiatan belajar. Termasuk didalamnya, yaitu karakteristik kepribadian siswa, atau 
sering kita kenal dengan faktor internal dari individu yang bersangkutan. Jika kedua hal tersebut tercipta dalam proses pembelajaran, maka individu dapat memiliki kemandirian dalam belajar (self directing in learning).

Sumarno ${ }^{17}$ kemandirian belajar merupakan proses perancangan dan pemantauan diri yang seksama terhadap proses kognitif dan afektif dalam menyelesaikan suatu tugas akademik.. Bandura dalam Sumarno ${ }^{18}$ menyarankan tiga langkah dalam melaksanakan kemandirian belajar yaitu mengamati dan mengawasi diri sendiri dan membandingkan. Hendra Surya 19 menyatakan kemandirian belajar adalah proses menggerakkan kekuatan atau dorongan dari dalam individu yang belajar untuk menggerakan potensi dirinya mempelajari obyek belajar tanpa ada tekanan atau pengaruh asing di luar dirinya. Dengan demikian belajar mandiri lebih mengarah pada pembentukkan kemandirian dalam cara-cara belajar.

Mandiri dalam belajar adalah aktifitas yang didorong oleh kemauan sendiri, pilihan sendiri dan tanggungjawab sendiri tanpa bantuan orang lain serta mampu mempertanggungjawabkan tindakannya. Siswa dikatakan telah mampu melakukan tugas belajar tanpa ketergantungan dengan orang lain. Ciri-ciri pokok mahasiswa mampu mandiri dalam belajar dapat dilihat dari bagaimana memulai belajarnya, mengatur waktu dalam belajar sendiri, melakukan belajar dengan cara dan teknik yang sesuai dengan kemampuan sendiri

17 Sumarmo, (2004). Kemandirian Belajar: Apa, Mengapa dan Bagaimana Dikembangkan pada Peserta Didik. Makalah disajikan pada Seminar Pendidikan Matematika di Jurusan Matematika FMIPA Universitas Negeri Yogyakarta, Tanggal 8 Juli 2004. Tidak diterbitkan http://math.sps.upi.edu/?p=61, h.2

${ }^{18}$ Sumarmo, Ibid. h.2

${ }^{19}$ Surya, Hendra, (2003). Kiat Mengajak Anak Belajar dan Berprestasi. Jakarta: PT. Grasindo, h. 114 serta mampu mengetahui kekurangan sendiri.

Sebagai syarat agar mahasiswa dapat belajar mandiri, mahasiswa tersebut harus memiliki dan melatih metode belajar yang baik, sehingga sejak awal dari pemberian tugas belajar, harus sudah timbul dalam pikiran mahasiswa untuk menata kegiatan belajar sendiri berdasarkan metodologi belajar yang baik dan pada tahapan-tahapan dalam proses belajar tersebut tidak diperintah. Mahasiswa mengetahui arah dan tujuan serta langkah yang harus diperbuat dalam menyelesaikan tugas yang dihadapkan kepadanya. Mahasiswa memiliki kemahiran dalam menyelesaikan tugas belajarnya dan mampu mengimplementasikan pengetahuan yang diperolehnya tersebut.

\section{Belajar Mandiri Sebagai Sistem Belajar}

Perkembangan pendidikan telah banyak bergerak maju dalam pembelajaran, diantaranya terarah pada pemenuhan kebutuhan belajar secara mandiri. Dosen atau pengelola pembelajaran hendaknya dapat memenuhi kebutuhan individu terhadap belajar mandiri.

Belajar individual/mandiri muncul sebagai jawaban atas masalah kualitas pendidikan. Diawali dari kelemahan pembelajaran klasikal yang mengabaikan keragaman individu, kemudian muncul pembelajaran individual yang menghargai perbedaan. Pembelajaran individual didefinisiskan sebagai usaha dari dosen atau pengelola perguruan tinggi untuk menyesuaikan pembelajaran dengan perbedaan individual diantara mahasiswa secara pribadi, sosial dan perkembangan akademik dengan lebih baik dari pembelajaran tradisional yakni pembelajaran tidak diindividualisasikan.

Belajar individual/mandiri merupakan upaya memberikan penghargaan perbedaan individu pebelajar. Sementara itu dalam pembelajaran klasikal hal tersebut 
diabaikan. Oleh karena itu strategi dalam kemandirian belajar, setiap individu belajar memang perlu diperhatikan, sebab pada hakikatnya individu itu belajar secara individual bukan bersama-sama dan diantara mereka memiliki persepsi, penerimaan dan pemrosesan informasi yang berbeda-beda.

Munculnya belajar mandiri kemudian membentuk sistem tersendiri yang dikenal dengan sistem belajar individual (SBI), sebagaimana Yusuf Hadi, ${ }^{20}$ menjelaskan bahwa belajar mandiri memiliki sistem sebagai berikut :

a. Falsafah dan Teori

1) Ontologi : Postulat bahwa (a) manusia dilahirkan dalam keadaan berbeda; (b) manusia mampu mempunyai kemampuan untuk belajar dan mengembangkan diri sesuai dengan potensi yang ada padanya dan lingkungan yang mempengaruhinya (c) manusia mempunyai keluwesan dan kemampuan untuk mengubah dan membentuk kepribadiaannya

2) Epistemologi : berdasarkan anggapan bahwa semua manusia dapat belajar apa saja, melalui apa saja, dari apa saja dengan cara yang sesuai dengan karakteristik dan kondisi masing-masing

3) Aksiologi : memiliki manfaat agar peserta didik dimungkinkan mengikuti pendidikan dan pelatihan sesuai dengan kondisi masingmasing.

b. Kebutuhan : kebutuhan yang dirasakan, kebutuhan yang dinyatakan, bersifat normative sesuai standar dan kebutuhan masa depan sebagai manusia

c. Peserta : penghargaan individual terhadap gaya dan cara belajar yang indi-

\footnotetext{
${ }^{20}$ Gurdish K. Gill Grauduate School of Education The University of Western Aaustralia http ://www.are.edu.au./07pap/gi107012.pdf pada tanggal 21 Mei 2008, h.251
}

vidual

d. Program : rencana yang dikembangkan untuk mengakomodasikan kebutuhan dan kemampuan untuk belajar dan mengembangkan diri.

e. Strategi : pendekatan menyeluruh dalam pembelajaran dan pedoman umum kerangka kegiatan

f. Materi pelajaran : sejumlah bahan yang perlu dikuasai sesuai kompetensi yang dibutuhkan

g. Produksi dan pengadaan belajar : pengembangan perangkat belajar, yang sesuai dengan kondisi dan model belajar mandiri.

h. Distribusi/penyebaran : delivery system terhadap materi dan bahan ajar yang dibutuhkan dengan mengikuti karakteristik belajar mandiri.

i. Kegiatan Belajar : insiatif proses pembelajaran yang diciptakan dandikondisikann sendiri oleh peserta sesuai dengan kebutuhannya.

j. Organisasi Penyelenggara : upaya efisiesnsi dan efektifitas kegiatan untuk mencapai tujuan.

k. Tenaga : sumber daya manusia yang diperlukan untuk terselenggaranya system belajar mandiri.

1. Sarana dan Prasarana :sumber daya pendukung yang diperlukan untuk terselenggaranya sistem belajar mandiri yang diprogramkan.

m. Bantuan dan Pengawasan : bagian dari managemen organisasi penyelenggara yang memungkinkan kendali proses mutu belajar.

n. Penilaian dan Penelitian : kegiatan mengevaluasi proses dan hasil sistem belajar mandiri yang diprogramkan dan dilakukan.

Pemahaman tentang belajar individual perlu dilakukan dengan mencermati latar belakang yang melandasi kebutuhan munculnya belajar mandiri pada mahasiswa. Kebutuhan belajar mandiri meliputi organisasi, strategi, program, materi, sarana 
prasarana, sumber daya manusia, perangkat dan kegiatan belajar, pengawasan, dan evaluasi. Komponen-komponen dalam system belajar perlu dirancang sesuai dengan kebutuhan mahasiswa, sehingga tujuan pembelajaran akan tercapai dengan baik.

3. Ciri-ciri Kemandirian Belajar

Mahasiswa mandiri dalam belajar adalah mahasiswa yang mampu berfikir kritis, bertanggung jawab atas tindakannya, tidak mudah terpengaruh pada orang lain, bekerja keras dan tidak tergantung pada orang lain. Ciri-ciri kemandirian belajar merupakan faktor pembentuk dari kemandirian belajar mahasiswa.,

Benchmark (dalam Keith Crome, Ruth Farrar and Patrick O'Connor, 21 menyatakan merupakan aspek integral dari pembelajaran otonom, adalah :

a. Kemampuan untuk memotivasi diri

b. Kemampuan untuk bekerja mandiri

c. Mampu mengelola pekerjaan secara mandiri

d. Pikiran yang fleksibel dan mudah beradaptasi

e. Mampu menghadapi situasi baru

f. Kemampuan untuk berpikir kreatif, kritis, dan mandiri.

Menurut Chabib Thoha ${ }^{22}$ membagi ciri kemandirian belajar dalam delapan jenis :

a. Mampu berpikir secara kritis, kreatif dan inovatif.

b. Tidak mudah terpengaruh oleh pendapat orang lain.

c. Tidak lari atau menghindari masalah.

d. Memecahkan masalah dengan berpikir mendalam.

21 Crome, Keith, Ruth Farrar and Patrick O'Connor, (2009). What is Autonomous Learning? Journal IISN: 2040-3674, ISSN-L: 1741-4164, Volume: 9, Number: 1, Start Page 111-126.

22 Thoha, Chabib, (1996). Kapita Selekta Pendidikan Islam. Yogyakarta : Pustaka Pelajar IKAPI, h.123-124 e. Apabila menjumpai masalah dipecahkan sendiri tanpa meminta

f. Berusaha bekerja dengan penuh ketekunan dan kedisiplinan.

g. Bertanggung jawab atas tindakannya sendiri.

Sedangkan menurut temuan Tuloli ${ }^{23}$ (1992:205) dalam hasil penelitiannya, mengemukakan bahwa ciri-ciri manusia mandiri adalah jeli melihat permasalahan, berani menghadapi masalah, memiliki gagasan dalam menghadapi masalah, ada usaha, ada optimisme, ada keuletan, dan memiliki pengetahuan dan upaya keterampilan.

Berdasarkan beberapa ciri kemandirian belajar yang telah dipaparkan, maka ciri-ciri kemandirian belajar yang paling menonjol yang dimiliki mahasiswa yaitu pertama; mahasiswa mengerti dan memahami motivasi dan kebutuhan belajarnya. Kedua; mahasiswa akan berusaha memecahkan berbagai persoalan yang berkaitan dengan materi belajar maupun factor-faktor penghambat yang mempengaruhi proses belajarnya. Ketiga; mahasiswa memiliki karakter optimisme dalam berbagai hal dan berusaha dengan segala keuletan, ketangguhan, kesabaran, dan kerja keras untuk mencapai apa yang diinginkan dan motivasinya, percaya pada kemampuan dirinya sendiri dan tidak tergantung pada orang lain. Keempat; mahasiswa selalu berani mencoba, berani mengahadapi tantangan dan resiko kegagalan serta berani bertanggung jawab dalam setiap tugas. Kelima; mahasiswa memiliki pikiran terbuka untuk menerima kritikan, jujur dan transparan, mudah menyesuaikan diri, berpikir realitis, kritis, kreatif, inovatif, dan logis. Keenam, mahasiswa pandai mengelola waktunya

23 Tuloli, J.H., (1991). Transformasi Potensi Generasi Muda Menuju Insan Mandiri: Menguak Kegiatan Pembina Pramuka di Indonesia, Disertasi Doktor. Bandung : FPS-IKIP. Tidak diterbitkan 
dengan efektif dan efisien, tidak suka membuang waktu dengan sia-sia, dan suka bekerja keras.

4. Faktor-faktor yang Mempengaruhi Kemandirian Belajar

Menurut Hasan Basri ${ }^{24}$ menjelaskan bahwa kemandirian belajar Mahasiswa dipengaruhi oleh beberapa faktor yaitu faktor yang terdapat di dalamnya dirinya sendiri (faktor endogen) dan faktor-faktor yang terdapat diluar dirinya sendiri (faktor eksogen).

a. Faktor Endogen (Internal) adalah semua pengaruh yang bersumber dari dalam dirinya sendiri, seperti keadaan keturunan dan konstitusi tubuhnya sejak dilahirkan dengan segala perlengkapan yang melekat padanya. Segala sesuatu yang dibawa sejak lahir adalah merupakan bekal dasar bagi pertumbuhan dan perkembangan individu selanjutnya. Bermacam-macam sifat dasar dari ayah dan ibu mungkin akan didapatkan didalam diri seseorang, seperti bakat, potensi intelektual dan potensi pertumbuhan tubuhnya.

b. Faktor Eksogen (Eksternal)

Faktor eksogen (Eksternal) adalah semua keadaan atau pengaruh yang berasal dari luar dirinya, sering juga disebut faktor lingkungan. Lingkungan kehidupan yang dihadapi individu sangat mempengaruhi perkembangan kepribadian seseorang, baik dari segi negative maupun positif. Lingkungan keluarga dan masyarakat yang baik terutama dalam bidang nilai dan kebiasaan-kebiasaan hidup akan membentuk kepribadian, termasuk pula dalam hal kemandirian.

Sementara itu Chabib Thoda ${ }^{25}$ menyebutkan faktor-faktor kemandirian dapat dibedakan dari dua arah, yakni :

24 Bahri, Hasan, (2000). Remaja Berkualitas (Problema Remaja dan Solusinya). Yogyakarta: Pustaka Pelajar, h. 54

25 Chabib Toha, Op.Cit., h. 124-125 a. Faktor dari Dalam

Faktor dari dalam diri anak adalah antara lain faktor kematangan usia dan jenis kelamin. Disamping itu inteligensia anak juga berpengaruh terhadap kemandirian mama.

b. Faktor dari luar

Adapun faktor dari luar yang mempengaruhi kemandirian anak adalah :

1) Kebudayaan, masyarakat yang maju dan kompleks tuntutan kehidupannya cenderung mendorong tumbuhnya kemandirian dibanding dengan masyarakat yang sederhana.

2) Keluarga, meliputi aktifitas pendidikan dalam keluarga, kecenderungan cara mendidik anak, cara memberikan penilaian kepada anak, bahkan sampai cara hidup orangtua berpengaruh terhadap kemandirian anak .

Muhammad Ali dan Muhammad Asrori 26 menyebutkan sejumlah faktor yang mempengaruhi perkembangan kemandirian, yaitu :

a. Gen atau keturunan orang tua. Orang tua memiliki sifat kemandirian tinggi seringkali menurunkan anak yang memiliki kemandirian juga.

b. Pola asuh orang tua. Cara orang tua mengasuh dan mendidik anak akan mempengaruhi perkembangan kemandirian anak remajanya.

c. Sistem pendidikan di sekolah. Proses pendidikan di sekolah yang tidak mengembangkan demokrasi pendidikan dan cenderung menekankan indoktrinasi tanpa argumentasi akan menghambat perkembangan kemandirian remaja sebagai siswa.

d. Sistem kehidupan di masyarakat. Sistem kehidupan masyarakat yang terlalu menekankan pentingnya hirarki struktur sosial, merasa kurang aman

\footnotetext{
${ }^{26}$ Muhammad Ali dan Muhammad Asrori, Op.Cit., h. 118-119
} 
atau mencekam serta kurang menghargai manifestasi potensi remaja dalam kegiatan produktif dapat menghambat kelancaran perkembangan kemandirian remaja atau siswa.

Faktor-faktor yang mempengaruhi kemandirian sangat menentukan tercapainya kemandirian seseorang, baik factor yang berasal dari dalam diri siswa sendiri, maupun yang berasal dari luar, yaitu lingkungan keluarga, perguruan tinggi, lingkungan sosial ekonomi dan lingkungan masyarakat.

Faktor-faktor tersebut mempunyai peranan yang sangat penting dalam kehidupan Selanjutnya akan menentukan seberapa jauh seorang individu bersikap dan berfikir secara mandiri dalam kehidupan selanjutnya. Dengan demikian dalam mencapai kemandirian seseorang tidak lepas dari faktor-faktor yang mempengaruhi kemandiriannya. Kemandirian mahasiswa sangat tergantung pada dan bagaimana ia melihat, merasakan dan melakukan aktifitas belajar atau kegiatan belajar sehari-hari dalam lingkungan tempat tinggalnya.

\section{KAJIAN TEORITIS PEMBELAJARAN KONSTRUKTIF}

\section{Pengetahuan dibangun atas dasar Pemikiran Konstruktif}

Menurut Asri Budiningsih

${ }^{27}$ pendekatan konstruktivistik adalah bukan pengetahuan kumpulan fakta dari suatu kenyataan yang sedang dipelajari, melainkan sebagian konstruksi kognitif seseorang terhadap objek, pengalaman, maupun lingkungannya. Pengetahuan bukanlah sesuatu yang sudah ada dan tersedia dan sementara orang lain tinggal menerimanya. Pengetahuan adalah sebagai suatu pembentukan yang terus menerus oleh seseorang yang setiap saat mengalami reorganisasi karena adanya pemahaman-

\footnotetext{
27 Asri Budiningsih, (2008). Belajar dan Pembelajaran. Jakarta:Rineka Cipta, h.56
}

pemahaman baru. Transformasi pengetahuan dalam konstruktivisme adalah pergeseran mahasiswa sebagai penerima pasif informasi menjadi pengkonstruksi aktif dalam proses pembelajaran. Pengetahuan selalu merupakan akibat dari suatu konstruksi kognitif, suatu realita melalui kegiatan mental seseorang. Pengetahuan yang dimiliki mahasiswa digunakan untuk membuat suatu hipotesis-hipotesis, menguji teori dan membuat suatu kesimpulankesimpulan. ${ }^{28}$

Pengetahuan yang dibangun dalam pikiran pebelajar didasarkan atas strukturstruktur kognitif atau skema yang telah ada sebelumnya, memberi basis teoretis untuk membedakan antara belajar bermakna dan belajar hafalan. Belajar secara bermakna, individu-individu harus memilih untuk menghubungkan pengetahuan baru dengan konsep-konsep yang relevan dan proporsiproporsi yang telah mereka ketahui. Dalam belajar hafalan, pengetahuan baru mungkin dapat dikuasai secara lebih sederhana dengan jalan mengingat kata demi kata secara harfiah dan arbitrer untuk digabungkan kedalam struktur pengetahuan yang berinteraksi dengan apa yang sudah ada sebelumnya. ${ }^{29}$

Dengan paham konstruktivisme, mahasiswa membangun pemahamannya sendiri dari pengalaman atau pengetahuan terdahulu. Pemahaman yang mendalam dikembangkan melalui pengalamanpengalaman belajar bermakna (akomodasi). Mahasiswa mampu mempraktekkan pengetahuan/pengalaman yang telah diperoleh dalam konteks kehidupan dan melakukan refleksi terhadap strategi pengembangan pengetahuan tersebut. Oleh karena itu, hakekat teori konstruktivisme adalah mahasiswa harus menjadikan

28 Anonim. (2002). What is Constructivism? http://thirteen.org/edoline/concept2, h. 5

29 Bodner, George.M. (1986). Constructivism A Theory of Knowledge. Purdue University.Journal of Chemical Education Vol. 63 No. 10. h.15 
informasi itu menjadi miliknya sendiri dan terus-menerus memeriksa informasiinformasi baru yang berlawanan dengan aturan-aturan lama dan memperbaiki aturan-aturan tersebut jika tidak sesuai lagi. Teori konstruktivis menuntut mahasiswa berperan aktif dalam pembelajaran mereka sendiri. Karena penekanannya keaktifan, maka strategi konstruktivis sering disebut sebagai pengajaran yang berpusat pada siswa (student centered instruction) yaitu pembelajaran terpusat pada mahasiswa, peranan dosen adalah membantu mahasiswa menemukan fakta, konsep, atau prinsip bagi diri mereka sendiri, bukan memberikan ceramah atau mengendalikan seluruh kegiatan di kelas.

\section{Implementasi pendekatan Konstruktif dalam Pembelajaran}

Bodner menjelaskan (1986:873) “ Knowledge is constructed as the learner strives to organize hisofher experience intermof preexisting mental structure". Dengan demikian belajar menurut pandangan konstruktivisme adalah proses memperoleh pengetahuan yang diciptakan atau dilakukan oleh siswa sendiri melalui transformasi pengalaman individu siswa.

Selanjutnya Briner ${ }^{30}$ menjelaskan :

"Another theory developed at about the same time (1910-1920) was constructivism. In this teaching and learning model, students construct their own knowledge by testing ideas based on prior knowledge and experience, applying these ideas to new situation, and integrating the new

30 Berns, Robert G. dan Patricia M. Erickson. (2001). Contextual Teaching and Learning: Preparing Students for the New Economy Tersedia dalam: http://www.nccte.org/publications/infosynthesis/ hig hlightzone/highlight 05.ctl.pdf. (8 Agustus 2006), h.1 knowledge gained with preexisting intellectual constructs. Rooted in the theories of John Dewey (1900) Constructivism calls for active participation in problem solving and critical thinking regarding an authentic learning activity that students find relevant and engaging".

Teori Bodner di atas menjelaskan bahwa ada teori lain yang dikembangkan pada waktu yang sama (1910-1920) adalah konstruktivisme . Dalam model ini, siswa membangun pengetahuan mereka sendiri dengan menguji ide-ide berdasarkan pengetahuan dan pengalaman sebelumnya, menerapkan ide-ide ini dengan situasi baru, dan mengintegrasikan pengetahuan baru yang diperoleh dengan yang sudah ada sebelumnya yang merupakan konstruksi intelektual . Berakar pada teori John Dewey ( 1900 ) Konstruktivisme merupakan partisipasi aktif dalam pemecahan masalah dan berpikir kritis tentang kegiatan belajar otentik bahwa siswa menemukan relevan dan menarik .

Konstruktivisme merupakan landasan filosofis (berfikir) pendekatan kontekstual. Pembelajaran yang berciri konstruktivisme menekankan terbentuknya pemahaman sendiri berdasarkan pengetahuan dari pengalaman yang dimiliki oleh mahasiswa. Karena itu mahasiswa perlu dibiasakan untuk memecahkan masalah, menemukan sesuatu yang berguna bagi dirinya dan mengembangkan ide yang ada pada dirinya. Atas dasar pengertian tersebut, prinsip dasar konstruktivisme yang dalam praktek pembelajaran harus dipegang oleh dosen adalah sebagai berikut :

a. Mahasiswa mendapatkan kesempatan seluas-luasnya untuk menemukan dan menetapkan idenya sendiri

b. Mahasiswa diberikan kebebasan untuk menerapkan strateginya sendiri dalam belajar

c. Pengetahuan mahasiswa tumbuh dan berkembang melalui pengalaman sendiri 
d. Pemahaman mahasiswa akan berkembang semakin dalam dan semakin kuat apabila diuji dengan pengalaman baru. ${ }^{31}$ Beberapa preposisi yang dapat dikemukakan sebagai implikasi dari teori konstruktivistik dalam praktek pembelajaran di perguruan tinggi sekarang ini adalah belajar adalah proses pemaknaan informasi baru, kebebasan merupakan unsur esensial dalam lingkungan belajar, strategi belajar yang digunakan menentukan proses dan hasil belajar, belajar pada hakekatnya memiliki aspek sosial dan budaya dan kerja kelompok dianggap sangat berharga.

Dalam pandangan konstrukivistik, kebebasan dipandang sebagai penentu keberhasilan karena kontrol belajar dipegang oleh mahasiswa itu sendiri. Tujuan pembelajaran konstruktivistik menekankan pada penciptaan pemahaman, yang menuntut aktivitas yang kreatif dan produktif dalam konteks nyata, yang dikehendaki oleh pembelajaran kontekstual.

Secara skematis dapat dikemukakan perbandingan antara pembelajaran tradisonal dan pembelajaran konstruktivistik dalam Tabel 2.4 sebagai berikut :

Tabel 2.4

Perbandingan Pembelajaran

Tradisional dan Konstruktivistik

\begin{tabular}{|l|l|}
\hline \multicolumn{1}{|c|}{$\begin{array}{l}\text { Pembelajaran } \\
\text { Tradisional }\end{array}$} & \multicolumn{2}{c|}{$\begin{array}{l}\text { Pembelajaran } \\
\text { Konstruktivistik }\end{array}$} \\
\hline $\begin{array}{l}\text { 1. } \\
\text { Penyajian kurikulum, } \\
\text { menggunakan pen- } \\
\text { dekatan induktif } \\
\text { (disajikan dari bagian- } \\
\text { bagian menuju kese- } \\
\text { luruhan) }\end{array}$ & $\begin{array}{l}\text { Penyajian } \\
\text { kurikulum } \\
\text { mernggunakan pen- } \\
\text { dekatan deduktif } \\
\text { (disajikan mulai dari } \\
\text { keseluruhan menuju } \\
\text { kebagian-bagian }\end{array}$ \\
\hline $\begin{array}{l}\text { 2. } \\
\text { Pembelajaran berjalan } \\
\text { secara rutinitas, for- } \\
\text { malistik dan kaku. }\end{array}$ & $\begin{array}{c}\text { 2. Pembelajaran didesain } \\
\text { dalam suasana yang } \\
\text { memberikan }\end{array}$ \\
\hline
\end{tabular}

31 Mansur, Muslich, (2007). KTSP Pembelajaran Berbasis Kompetensi dan Kontekstual, Jakarta: Bumi Aksara, h. 44

\begin{tabular}{|c|c|c|}
\hline & $\begin{array}{l}\text { Lebih didasarkan ku- } \\
\text { rikulum yang bersifat } \\
\text { formalistik }\end{array}$ & $\begin{array}{l}\text { kebebasan siswa untuk } \\
\text { mengekspresikan idea } \\
\text { tau gagasan }\end{array}$ \\
\hline 3. & $\begin{array}{l}\text { Kegiatan kurikulum } \\
\text { lebih berorientasi pa- } \\
\text { da buku pegangan/tek } \\
\text { yang dimiliki } \\
\text { sekolah/guru } \\
\text { Akibatnya } \\
\text { pembelajaran tidak } \\
\text { didasarkan atas materi } \\
\text { atau tujuan dalam } \\
\text { kurikulum tetapi } \\
\text { kepada urutan baku } \\
\text { panduan }\end{array}$ & $\begin{array}{l}3 \text { Kegiatan kurikulum } \\
\text { lebih dikaitkan dengan } \\
\text { realitas dalam } \\
\text { kehidupan masyarakat. } \\
\text { Kegiatan kurikulum } \\
\text { atau pembelajaran } \\
\text { cenderung } \\
\text { menggunakan model } \\
\text { pembelajaran } \\
\text { kooperatif (kerjasama) }\end{array}$ \\
\hline 4. & $\begin{array}{l}\text { Peserta didik yang } \\
\text { belajar lebih dipan- } \\
\text { dang sebagai obyek } \\
\text { yang tidak memilki } \\
\text { pengetahuan apa-apa } \\
\text { (botol kosong). } \\
\text { Asumsi ini me- } \\
\text { lahirkan pembelajaran } \\
\text { hanya sekedar } \\
\text { menyampaikan materi } \\
\text { kepada siswa. Aspek } \\
\text { pemahaman mudah } \\
\text { dinafikan oleh guru }\end{array}$ & $\begin{array}{l}\text { Peserta didik dipahami } \\
\text { sebagai individu yang } \\
\text { memiliki potensi un- } \\
\text { tuk mengembangkan } \\
\text { materi pelajaran. }\end{array}$ \\
\hline 5 & $\begin{array}{l}\text { Penilaian atau test } \\
\text { hasil belajar dipan- } \\
\text { dang sebagai bagian } \\
\text { dari proses yang tid- } \\
\text { ak terpisahkan dari } \\
\text { pembelajaran dan } \\
\text { seringkali dilakukan } \\
\text { pada akhir pelajaran } \\
\text { dengan cara testing }\end{array}$ & $\begin{array}{l}5 \text { Penilaian atau test hasil } \\
\text { belajar dilakukan } \\
\text { secara progresif dan } \\
\text { melalui penilaian } \\
\text { karya siswa. Dalam } \\
\text { konteks sekarang biasa } \\
\text { disebut test fortofolio }\end{array}$ \\
\hline 6 & $\begin{array}{l}\text { Pembelajaran hanya } \\
\text { memiliki target } \\
\text { menghabiskan materi } \\
\text { pelajaran, kurang } \\
\text { memperhatikan } \\
\text { kualitas pemahaman } \\
\text { siswa terhadap mate- } \\
\text { ri yang disampaikan. }\end{array}$ & $\begin{array}{c}6 \text { Pembelajaran lebih } \\
\text { didasarkan atas proses } \\
\text { sehingga siswa-siswa } \\
\text { banyak belajar dan } \\
\text { bekerja di dalam } \\
\text { lingkaran kelompok } \\
\text { (kolektif) }\end{array}$ \\
\hline
\end{tabular}

Sumber: Mansur, Muslich, (2007). KTSP

Pembelajaran Berbasis Kompetensi dan

Kontekstual, Jakarta: Bumi Aksara, h. 45

Pada tabel di atas, sangat jelas menunjukkan adanya perbedaan antara pembelajaran konstruktif dengan pembelajaran tradisional. Pembelajaran konstruktif lebih menekankan adanya kebebasan mahasiswa untuk mengembangkan materi pembelajaran berdasarkan realitas kehidupan shari-hari, sehingga lebih banyak melibatkan 
mahasiswa belajar dan bekerja sama (membuat tugas portofolio).

Selanjutnya Glasersfeld, ${ }^{32}$ menyebut bahwa terdapat lima elemen belajar yang konstruktivistik yaitu : (1) pengaktifan pengetahuan yang sudah ada (activating knowledge); (2) pemerolehan pengetahuan baru (acquiring knowledge) dengan cara mempelajari secara keseluruhan lebih dulu, kemudian memperhatikan detailnya; (3) pemahaman pengetahuan (understanding knowledge), yaitu dengan cara menyusun konsep sementara (hipotesis), melakukan sharing kepada orang lain agar mendapat tanggapan (validasi) dan atas dasar tanggapan itu, konsep tersebut direvisi dan dikembangkan; (4) mempraktekkan pengetahuan dan pengalaman tersebut (applying knowledge); dan (5) melakukan refleksi (reflecting knowledge) terhadap strategi pengembangan pengetahuan tersebut.

Sedangkan Tasker ${ }^{33}$ mengemukakan tiga penekanan dalam teori belajar konstruktivisme sebagai berikut. Pertama; adalah peran aktif mahasiswa dalam mengkonstruksi pengetahuan secara bermakna. Kedua; adalah pentingya membuat kaitan antara gagasan dalam pengkonstruksian secara bermakna. Ketiga adalah mengaitkan antara gagasan dengan informasi baru yang diterima. Wheatley ${ }^{34}$ mendukung pendapat di atas dengan mengajukan dua prinsip utama dalam pembelajaran dengan teori belajar konstruktivisme. Pertama; pengetahuan tidak dapat diperoleh secara pasif, tetapi secara aktif oleh struktur kognitif mahasiswa. Kedua; fungsi kognisi bersifat

32 Komalasari, K. (2010). Pembelajaran

Kontekstual, Konsep dan Aplikasi. Bandung: PT. Refika Aditama, h.87

33 Tasker, R. 1992. Effective Teaching: What Can a Constructivist View of Learning Offer. The Australian Science Teacher JouTyrnal. 38 (1), h.30

${ }^{34}$ Wheatley, G.H. 1991. Constructivist Perspective on Science and Mathematics Learning. Science Education Journal. 75 (1), h.12 adaptif dan membantu pengorganisasian melalui pengalaman nyata yang dimiliki mahasiswa.

Pembelajaran konstruktif membantu mahasiswa menghubungkan antara pengetahuan awal yang sudah terbentuk secara terstruktur dalam pemikiran mahasiswa dengan pengetahuan baru yang diterima secara aktif selanjutnya membentuk sebuah organisasi pengetahuan yang saling berkaitan. (struktur kognitif baru)

Konstruktivisme sosial yang dikembangkan oleh Vigotsky adalah bahwa belajar bagi anak dilakukan dalam interaksi dengan lingkungan sosial maupun fisik. Penemuan atau discovery dalam belajar lebih mudah diperoleh dalam konteks sosial budaya seseorang.

Adapun implikasi dari teori belajar konstruktivisme dalam pendidikan sebagaimana yang dijelaskan oleh Poedjiaji 35 adalah sebagai berikut : (1) tujuan pendidikan menurut teori belajar konstruktivisme adalah menghasilkan individu atau anak yang memiliki kemampuan berfikir untuk menyelesaikan setiap persoalan yang dihadapi; (2) kurikulum dirancang sedemikian rupa sehingga terjadi situasi yang memungkinkan pengetahuan dan keterampilan dapat dikonstruksi oleh peserta didik. Selain itu, latihan memecahkan masalah seringkali dilakukan melalui belajar kelompok dengan menganalisis masalah dalam kehidupan sehari-hari; dan (3) peserta didik diharapkan selalu aktif dan dapat menemukan cara belajar yang sesuai bagi dirinya. Dosen/Guru hanyalah berfungsi sebagai mediator, fasilitor, dan teman yang membuat situasi yang kondusif untuk terjadinya konstruksi pengetahuan pada diri peserta didik.

35 Poedjiadi, A. (1999),Pengantar Filsafat Ilmu bagi Pendidik. Bandung: Yayasan Cendrawasih, h.63 
Pembelajaran tidak terpisahkan dengan kegiatan pembelajaran. Ditjen Dikdasmen ${ }^{36}$ menjabarkan kecenderungan tentang belajar berdasarkan konstruktivisme tersebut sebagai berikut :

a. Proses belajar, meliputi : (1) belajar tidak hanya sekedar menghafal, akan tetapi siswa harus mengonstruksikan pengetahuan sendiri; (2) Siswa belajar dari mengalami, siswa mencatat sendiri pola-pola bermakna dari pengetahuan baru (3) Pengetahuan yang dimiliki seseorang terorganisasi dan mencerminkan pemahaman yang mendalam tentang sesuatu persoalan (subject matter); (4) Pengetahuan tidak dapat dipisah-pisahkan menjadi fakta-fakta atau proposisi yang terpisah, tetapi mencerminkan keterampilan yang dapat diterapkan ; (5) Manusia mempunyai tingkatan yang berbeda dalam menyikapi situasi baru; (6) Siswa perlu dibiasakan memecahkan masalah, menemukan sesuatu yang berguna bagi dirinya, dan bergelut dengan ide-ide; (7) Proses belajar dapat mengubah struktur otak. Perubahan struktur otak itu berjalan terus seiring dengan perkembangan organisasi pengetahuan dan keterampilan seseorang.

b. Transfer belajar, meliputi : (1) Siswa belajar dari mengalami sendiri, bukan dari pemberian orang lain; (2) Keterampilan dan pengetahuan itu diperluas dari konteks yang terbatas (sempit), sedikit demi sedikit; 3) Penting bagi siswa tahu untuk apa ia belajar, dan bagaimana ia menggunakan pengetahuan dan keterampilam itu.

c. Siswa sebagai pembelajar, meliputi : (1) Siswa memiliki kecenderungan untuk belajar dengan cepat hal-hal yang baru, (2) Strategi belajar itu penting. Siswa dengan muvdah mempelajari sesuatu yang baru. Akan tetapi untuk hal-hal yang sulit, strategi belajar amat penting; (3) Peran guru membantu menghubungkan antara yang baru dan yang sudah diketahui; (4) Tugas guru memfasilitasi agar informasi bermakna, memberi kesempatan pada siswa untuk menemukan dan menerapkan ide mereka sendiri dan menyadarkan siswa untuk menerapkan strategi mereka sendiri.

d. Pentingnya lingkungan belajar, meliputi : (1) Belajar efektif itu dimulai dari lingkungan belajar yang berpusat pada siswa; (2) Pembelajaran harus berpusat pada bagaimana cara siswa menggunakan pengetahuan baru mereka. Strategi belajar lebih penting daripada hasilnya; (3) Umpan balik amat penting bagi siswa yang berasal dari proses penilaian yang benar; (4) Menumbuhkan komunitas belajar dalam bentuk kerja kelompok itu penting.

Dengan demikian kontruktivisme memberi penekanan pada keaktifan mahasiswa dalam pembelajaran. Sehingga pembelajaran merupakan proses penyiapan mahasiswa untuk membantu pemahaman dan pola pemikiran secara mandiri tanpa intervensi berlebihan dari pihak luar (pendidik). Melalui pendekatan konstruktivisme, belajar bagi mahasiswa tidak lagi merupakan "menerima" apa saja yang diberikan oleh pendidik, tetapi secara aktif dan kreatif "membina" pengetahuan yang sudah ada dan mentraformasikan dengan pengetahuan yang ada. Dengan itu ilmu dipahami sebagai suatu yang tidak "dipindahkan" tetapi "dibina" dan "diproses" dalam struktur kognitif si belajar. Dalam proses itu si belajar akan menyesuaikan pengetahuan yang diterima dengan pengetahuan yang sudah ada sebelumnya untuk membina pengetahuan yang sudah ada sebelumnya untuk membina pengetahuan baru dalam pikirannya.

\footnotetext{
${ }^{36}$ Komalasari, Op.Cit. h. $89-90$
} 
Selanjutnya M. Saekhan Muchit, 37 menyatakan bahwa pembelajaran akan efektif jika didasarkan pada empat komponen dasar, antara lain: (1) pengetahuan (knowledge), yaitu pembelajaran harus mampu dijadikan sarana untuk tumbuh kembangnya pengetahuan siswa; (2) keterampilan (skill), pembelajaran harus benar-benar memberikan keterampilan siswa, baik keterampilan intelektual (kognitif), keterampilan moral (afektif), dan keterampilan mekanik (psikomotorik); (3) sifat alamiah (dispositions), proses pembelajaran harus benar-benar berjalan secara alamiah, tanpa adanya paksaan dan tidak semata-mata rutinitas belaka; (4) perasaan (feeling), perasaan ini bermakna perasaan atau emosi atau kepekaan. Oleh sebab itu, pembelajaran harus mampu menumbuhkan kepekaan sosial terhadap dinamika dan problematika kehidupan masyarakat.

M. Saekhan Muchit, 38 menyatakan bahwa masing-masing elemen atau faktor dalam pembelajaran harus diberdayakan secara optimal. Dosen dan mahasiswa mutlak melakukan pergeseran asumsi atau paradigma dalam pembelajaran. Mahasiswa, menurut pandangan konstruktivistik, dalam proses pembelajaran harus aktif melakukan kegiatan, aktif berpikir, menyusun konsep dan memberi makna tentang hal-hal yang sedang dipelajari. Paradigma konstruktivistik, memandang mahasiswa sebagai pribadi yang sudah memiliki kemampuan awal sebelum mempelajari sesuatu. Mahasiswa dipahami sebagai pribadi yang memiliki kebebasan untuk membangun ide atau gagasan tanpa harus diintervensi oleh siapapun dengan kata lain mahasiswa

37 McAshan, M. (1981). Competency Based Education and Behaviour Objectives. New Jersey: Englewood Cliffs, Educational Tecnology Publication Inc.h.74 diposisikan sebagai manusia dewasa yang memiliki modal awal pengetahuan

\section{PEMBELAJARAN KONSTRUKTIF MEMBENTUK KEMANDIRIAN MAHASISWA DALAM BELAJAR}

Model pembelajaran konstruktivisme dapat mengembangkan pengetahuan bagi peserta didik, melalui materi atau konsep yang dipelajari. Mahasiswa melakukan sendiri kegiatan penelitian atau pengamatan langsung, menganalisis sesuai dengan materi yang dipelajari sehingga mahasiswa dapat menyalurkan ide-ide baru sesuai dengan pengalaman dan mengaitkannya dengan dunia nyata untuk menemukan fakta yang sesuai dengan kajian teori dan menemukan makna dari apa yang dipelajarinya dan dapat bermanfaat bagi kehidupannya.

Rasulullah menganjurkan agar memberikan pendidikan dan pengajaran yang sesuai dengan bakat, minat, kecenderungan, kecerdasan, dan latar siswa, sebagaimana dalam sabdanya : "Ajarilah anakmu sesuai dengan kadar kesanggupan akalnya" Hadits ini menjelaskan bahwa Nabi menganjurkan agar peserta didik diberikan peluang sebesar-besarnya untuk menggali dan mengembangkan pengetahuan dan keterampilannya yang berguna bagi kehidupannya sesuai dengan potensi-potensi atau fitrah yang dimilikinya.

Implementasi teori belajar Konstruktivisme pada materi akhlak yaitu mahasiswa memahami materi yang disampaikan oleh dosen, terdapat beberapa macam cara yang ditempuh. Cara itu dapat memilih metode pembelajaran maupun model pembelajaran yang tepat. Dengan menggunakan metode belajar yang sesuai untuk menumbuh kembangkan karakter mandiri, tujuan yang diharapkan akan tercapai atau dapat terlaksana dengan baik. Penerapan metode mengajar harus memperhatikan partisipasi siswa untuk terlibat aktif dalam proses 
pembelajarannya. Mahasiswa dirangsang untuk menyelesaikan problem-problem baik secara individu maupun kelompok, yang pada akhirnya dapat melatih mahasiswa untuk belajar mandiri dalam mengembangkan pemikirannya dan mahasiswa pun tidak selalu pembelajarannya pada dosen. Sebagaimana firman Allah SWT surat An nahl ayat 125 :

"serulah (manusia) kepada jalan

Tuhan-mu dengan hikmah dan pelajaran yang baik dan bantahlah mereka dengan cara yang baik.

Sesungguhnya Tuhanmu Dialah yang lebih mengetahui tentang siapa yang tersesat dari jalan-Nya dan Dialah yang lebih mengetahui orang-orang yang mendapat petunjuk."

Ayat di atas menjelaskan bahwa dosen sebagai tenaga pendidik hendaknya berusaha agar dapat menyampaikan materi/pembelajaran dengan baik dan selalu berusaha mengembangkan strategi dan metode yang sesuai dengan tingkat kebutuhan mahasiswa dan kemajuan IPTEK agar tujuan pembelajaran dapat tercapai dengan baik. Dalam upaya menanamkan konsep, dalam hal ini materi pokok tentang pembelajaran PAI, tidak cukup hanya sekedar ceramah. Pembelajaran akan lebih bermakna jika mahasiswa diberi kesempatan untuk tahu dan terlibat secara aktif dalam menemukan konsep dari faktafakta yang dilihat dari lingkungan dengan bimbingan dosen. Dengan demikian, siswa diharapkan mampu menghubungkan antara pengetahuan yang dimilikinya dengan penerapannya dalam kehidupan mereka sebagai anggota keluarga atau masyarakat.

Kemandirian adalah kepercayaan mahasiswa pada kemampuannya membangun pelajarannya sendiri. Pembelajaran konstruktif membantu mahasiswa berpikir dan bertindak serta mengembangkan sikap mandiri. Selain itu, pendekatan kontstruktivisme dapat menimbulkan spontanitas dan kesadaran dalam melaksanakan tugas-tugasnya secara sendiri. Komponen pembelajaran konstruktif dapat memunculkan daya inisiatif, kreatif dan keyakinan anak terhadap kemampuan sendiri, menumbuhkan sikap dapat menerima diri sendiri dan mahasiswa saling menghargai dan memahami perbedaannya diantara mahasiswa satu dengan yang lain yang akan mewujudkan suasana sosiomoral dalam kelas.

Pembelajaran mandiri adalah suatu proses belajar yang mengajak mahasiswa melakukan tindakan mandiri yang melibatkan terkadang satu orang biasanya satu kelompok. Tindakan mandiri itu dirancang untuk menghubungkan pengetahuan akademik dengan kehidupan siswa sehari-hari sedemikian rupa untuk mencapai tujuan yang bermakna. Tujuan ini mungkin menghasilkan hasil yang nyata maupun yang tidak nyata. Pembelajaran mandiri membangkitkan antusiasme yang sama pada anak-anak dari taman kanakkanak hingga universitas. Bebas mengembangkan minat dan bakat mereka. Mahasiswa selalu bersemangat mengajukan pertanyaan, mengadakan penyelidikan, dan melakukan berbagai percobaan. Brooks \& Brooks, ${ }^{38}$ menjelaskan tentang 1993 : 103) Langkahlangkah agar siswa memiliki kemandirian belajar adalah sebagai berikut :

1. Mengambil Tindakan

Mahasiswa berpartisipasi aktif dalam belajar dan langsung dapat memahami dan peduli tentang informasi baru. Souders \& Prescott, ${ }^{39}$ mendefinisikan bahwa belajar aktif yang disebut belajar langsung adalah belajar yang membuat

\footnotetext{
${ }^{38}$ Brooks, J.G. \& Brooks, M.G., (1993). In Search of Understanding: The Cas for Constructivist Classrooms, Alexandria, VA: Association for Supervision and Curriculum Development, h.103

39 Souders, John dan Carolyn Prescott, (1999). A Case for Contextual Learning School in Middle. h.7
} 
pelajaran melekat. Mencari dan menggabungkan informasi secara aktif di tempat kerja, masyarakat, maupun ruang kelas, lalu menggunakannya untuk alasan tertentu akan menyematkan informasi tersebut dalam ingatan. Pembelajaran mandiri yang menekankan pada tindakan, memberikan kesempatan pada otak untuk merasakan dunia luar dengan cara-cara yang tak terhitung. Sizer, 40 juga menyatakan bahwa tindakan fisik langsung memperkuat ingatan dalam belajar.

2. Mengajukan Pertanyaan Brooks \& Brooks, ${ }^{41}$ menjelaskan bahwa untuk menjadi mandiri, baik belajar dan bekerja sendiri maupun dalam kelompok, peserta didik harus bisa mengajukan pertanyaan- pertanyaan menarik, membuat pilihan yang bertanggung jawab, berpikir kritis dan kreatif.

Dengan demikian, pertanyaanpertanyaan yang tajam dapat menyempurnakan keyakinan dan menjelaskan berbagai kejadian. Untuk bisa mengerti, mahasiswa harus mencari makna. Untuk mencari sebuah makna, siswa harus mempunyai kesempatan untuk membentuk dan mengajukan pertanyaan pertanyaan.

\section{Membuat Pilihan}

Lewin \& Tsucida, ${ }^{42}$ menjelaskan bahwa selain mengajukan pertanyaan, mahasiswa dengan pembelajaran mandirinya membuat pilihan-pilihan cerdas. Mahasiswa dengan pembelajaran mandiri tidak hanya memilih rancangan kerja, tetapi juga memutuskan bagaimana mereka harus berperan serta. Mahasiswa memilih berpartisipasi dalam rencana kerja yang paling sesuai dengan minat pribadi dan

\footnotetext{
40 Sizer, Theodore, (1992). Horace's School, New York : Houghton Mifflin, h. 85

${ }^{41}$ Brooks, J.G. \& Brooks, M.G., Ibid., h.54

${ }^{42}$ Lewin, C., \& Tsuchida, L., The Basic in Japan. The Three C.s., Educational Leadership (Maret 3236), 1998, h. 32
}

bakat mereka. Mereka juga memilih gaya belajar yang paling tepat sambil mencari keterkaitan antara tugas sekolah dan kehidupan keseharian mereka. Mahasiswa dengan pembelajaran mandirinya dapat memilih cara mendapatkan informasi, misalnya dengan mengamati, mendengarkan, membaca, atau berdiskusi. Mereka mungkin melakukan riset dengan cara menonton video, mendengarkan kaset, membaca buku, atau melakukan interview. Pembelanjaran mandiri membebaskan peserta memilih cara belajar terbaik yang paling sesuai dan pola ini menyesuaikan minat dan bakat mereka. Pola belajar harus dapat membantu mahasiswa untuk mencapai keunggulan. Mahasiswa dapat memilih belajar yang menyenangkan sekaligus bermakna.

\section{Membangun Kesadaran Diri}

Pilihan yang bijaksana dan tindakan yang cerdas dibentuk oleh pengetahuan tentang diri atau kesadaran diri. Kesadaran diri dapat ditemukan oleh mahasiswa di ruang kelas ketika mereka menemukan manfaat dari memahami kecerdasan emosional. Salah satu dari keuntungannya adalah belajar mengendalikan emosi. Orang dapat mengendalikan emosi dengan mengarahkan pemikiran mereka ke objek lain atau mencoba bersikap adil pada orang yang tingkah lakunya mengesalkan mereka. Pengendalian emosi berasumsi bahwa menyadari perasaan saat-saat tertentu, yaitu pada saat seseorang mengalami perasaan tersebut.

Kesadaran diri yaitu kemampuan untuk merasakan perasaan saat perasaan tersebut muncul. Kemampuan ini membuat kendali diri menjadi sesuatu yang mungkin. Kemampuan ini juga dapat mengilhami tindakan yang akan diambil. Kesadaran diri juga meliputi pengetahuan tentang keterbatasan kekuatan kita, dan juga untuk mengetahui bagaimana pandangan orang lain terhadap kita. Kalau kita menyadari bagaimana orang lain memperhatikan kita, 
mungkin kita dapat memperbaiki hubungan kita dengan mereka, yang juga dapat meningkatkan kemampuan untuk bekerja sama dalam kelompok. Kerjasama dengan anggota kelompok tentunya akan berlangsung lebih baik diantara mereka yang memiliki kescerdasan emosional yang tinggi. ${ }^{43}$

\section{Kerjasama}

Kerjasama adalah komponen penting dalam system pembelajaran konstruktif, misalnya sekolah bekerja sama dengan mitra bisnis dan masyarakat, sekolah menengah pertama dan sekolah menengah atas, guru bekerjasama dengan orang tua siswa dan rekan kerja mereka. Para mahasiswa dengan pembelajaran mandiri ini biasanya bekerjasama dalam kelompok kelompok kecil dan otonomi. Kehidupan yang alami adalah berinteraksi, bekerjasama, dan berhubungan dengan orang lain. Mahluk hidup membentuk kelompok dan bergabung menciptakan bentuk kehidupan yang baru yang terdiri dari beragam organisme. Alam juga bekerjasama, tidak bersaing. Kesuksesan adalah sesuatu yang dibagi bersama.

Mahasiswa dengan pola pengaturan diri yang telah menguasai keahliannya dalam dan dapat bekerjasama akan mudah mengidentifikasi dan menyelesaikan tugastugas penting yang bermakna dan sejalan dengan tugas-tugas sekolah dan kehidupan sehari hari. Johnson 44 menjelaskan langkah-langkah pembelajaran mandiri bagi siswa adalah sebagai berikut :

a. Mahasiswa mandiri menetapkan tujuan

b. Mahasiswa mandiri membuat rencana

c. Mahasiswa mandiri mengikuti rencana dan mengukur kemajuan diri

\footnotetext{
${ }^{43}$ Goleman, D (1995), Emotional Intellegence, New York : Batam Books

44 Johnson, E.B., 2002, Contextual Teaching and Learning: What It Is and Why It Is Here to Stay, California USA: Corwin Press. Inc.h.172
}

d. Mahasiswa mandiri membuahkan hasil akhir

e. Mahasiswa mandiri menunjukan kecakapan melalui penilaian auatentik

Posisi dosen dalam pembelajaran konstruktif, yaitu sebagai pembimbing, pengarah, dan fasilitator. Mahasiswa menemukan, membangun, melaksanakan, dan mengevaluasi pembelajarannya. Tugas dosen memberikan arahan agar pembelajaran berjalan baik, lancar dan mencapai tujuan pembelajaran. Utamanya juga dosen hendaknya lebih memperhatikan mahasiswa yang pasif dan kurang kreatif, agar semua mahasiswa bimbingannya memiliki kompetensi sesuai dengan tujuan yang akan dicapai.

Fungsi dosen sebagai pengawas adalah mengontrol prilaku-prilaku mahasiswa agar tidak menyimpang dari aturan-aturan dalam belajar. Bilamana prilaku mahasiswa menyimpang dari aturan-aturan sekolah maka mahasiswa tersebut perlu diberikan nasehat-nasehat dan arahan-arahan agar tidak melakukan hal seperti itu lagi.

Dosen sebagai evaluator, maka fungsi dosen adalah menilai perkembangan hasil belajar mahasiswa. Tanggung jawab dosen adalah berkewajiban untuk mengetahui perkembangan belajar mahasiswa melalui proses penilaian, sehingga mahasiswa yang belum berhasil, perlu dibantu dan dicari cara-cara yang tepat dalam mengatasi kesulitan belajarnya sehingga hasil belajar mereka meningkat. Kesulitan belajar yang dialami oleh mahasiswa bisa berasal dari kemampuan akademiknya seperti lamban dalam menangkap pelajaran, dan bisa juga berasal dari cara-cara mengajar dosen yang kurang profesional. Hasil belajar mahasiswa rendah mungkin disebabkan strategi dan metode mengajar dosen yang kurang tepat. Dosen mengajar tidak memberikan contoh-contoh yang konkrit yang mudah dipahami oleh mahasiswa misalnya contoh yang berasal dari kehidupan mahasiswa sehari-hari. Dosen mengajar menggunakan 
alat peraga atau media yang tidak sesuai dengan materi pelajaran yang diajarkan. Dosen tidak sering memberikan latihan atau tugas individual maupun tugas kelompok untuk mendorong mahasiswa belajar mendalami materi pelajaran yang sudah disampaikan oleh dosen di kelas.

Bilamana dosen mampu menjalankan fungsinya, sebagaimana diuraikan di atas, maka dapatlah diharapkan bahwa proses pendidikan yang dilakukan oleh dosen akan mampu menghasilkan mahasiswa yang berprestasi, educated dan bermoral.

\section{PENUTUP}

\section{Kesimpulan}

Pembelajaran konstruktivisme adalah pengembangan pengetahuan bagi peserta didik, dilakukan melalui materi atau konsep yang dipelajari. Mahasiswa dengan kemandiriannya, melakukan sendiri kegiatan penelitian atau pengamatan langsung, menganalisis materi pembelajaran sehingga mahasiswa dapat menyalurkan ide-ide baru sesuai dengan pengalaman dan mengaitkannya dengan dunia nyata untuk menemukan fakta yang sesuai dengan kajian teori sehingga mahasiswa dapat menemukan makna dari apa yang dipelajarinya dan dapat bermanfaat bagi kehidupannya.

\section{Saran}

Hendaknya dosen melaksanakan tugastugasnya sebagai pendidikan sesuai dengan fungsi dosen dalam pembelajaran konstruktutif, yaitu sebagai fasilitator (pembimbing dan pengarah) dan pengawas adalah mengontrol prilaku-prilaku mahasiswa agar tidak menyimpang dari aturan-aturan dalam belajar. Dosen sebagai evaluator, maka fungsi dosen adalah menilai perkembangan hasil belajar mahasiswa. Dosen juga melakukan evaluasi diri agar dapat memperbaiki program pembelajaran yang dirancangnya dan menerapkannya dalam proses pembelajaran di kelas yang berorientasi pada kemajuan mahasiswa..

\section{DAFTAR PUSTAKA}

Ali, Muhammad \& Muhammad, Asrori, (2004). Psikologi Remaja (Perkembangan Peserta Didik). Jakarta : Bumi Aksara.

Anita Lie., Cooperative Learning (mempraktekkan Cooperative Learning di Ruang-RuangKelas). Jakarta : Grasindo.

Anonim. (2002). What is Constructivism? http://thirteen.org/edoline/concept2,

Asihwardji, Danuyasa, (Edt.), (1996). Ensiklopedi Psikologi (Pembahasan dan Evaluasi Lengkap Berbagai Topik, Teori, Riset, dan Penemuan Baru Dalam Ilmu Psikologi), Terjemahan Ediati Kamil, Jakarta: Arcan.

Asri Budiningsih, (2008). Belajar dan Pembelajaran. Jakarta:Rineka Cipta.

Bahri, Hasan, (2000). Remaja Berkualitas (Problema Remaja dan Solusinya). Yogyakarta: Pustaka Pelajar.

Berns, Robert G. dan Patricia M. Erickson. (2001). Contextual Teaching and Learning: Preparing Students for the New Economy Tersedia dalam: http://www.nccte.org/publications/inf osynthesis/hig hlightzone/highlight 05.ctl.pdf. (8 Agustus 2006).

Bodner, George.M. (1986). Constructivism A Theory of Knowledge. Purdue University. Journal of Chemical Education Vol. 63 No. 10.

Brooks, J.G. \& Brooks, M.G., (1993). In Search of Understanding: The Cas for Constructivist Classrooms, Alexandria, VA: Association for Supervision and Curriculum Development.

Candy, Philip C. (1975), Independent Learning : some Ideas from Literature" San Fransisco : JosseyBass Inc, Publishers. 
Crome, Keith, Ruth Farrar and Patrick O'Connor, (2009). What is Autonomous Learning? Journal IISN: 2040-3674, ISSN-L: 1741-4164, Volume: 9, Number: 1, Start Page 111-126.

Echlos, John M. dan Hasan Shadily. (2003.) AnEnglish-Indonesian Dictionary, Jakarta: PT. Gramedia Pustaka Utama.

Gurdish K. Gill Grauduate School of Education The University of Western Aaustralia $\underline{\mathrm{http}}$ ://www.are.edu.au./07pap/gi107012.p df pada tanggal 21 Mei 2008.

Goleman, D (1995), Emotional Intellegence, New York : Batam Books

Johnson, E.B., 2002, Contextual Teaching and Learning: What It Is and Why It Is Here to Stay, California USA: Corwin Press. Inc.

Koesoema, Doni, (2007). Pendidikan Karakter, Strategi Mendidik Anak di Zaman Global, Jakarta: PT. Gramedia Widiasarana Indonesia.

Komalasari, K. (2010). Pembelajaran Kontekstual, Konsep dan Aplikasi. Bandung: PT. Refika Aditama.

Lewin, C., \& Tsuchida, L. (1998). The Basic in Japan. The Three C.s., Educational Leadership (Maret 3236).

Lickona, T. (1991). Education for character: How our schools can teach respect and responsibility. New York: Bantam Books.

Mansur, Muslich, (2007). KTSP Pembelajaran Berbasis Kompetensi dan Kontekstual, Jakarta: Bumi Aksara.

McAshan, M. (1981). Competency Based Education and Behaviour Objectives. New Jersey: Englewood Cliffs, Educational Tecnology Publication Inc.

Masrun, (1988). Studi Tentang Kemandirian Sebagai Kualitas
Kemandirian, Makalah Seminar IlmuIlmu Sosial: Mempersiapkan Masyarakat Masa Depan di Ujung Pandang.

Mulyana, R, 2004, Mengartikulasikan Pendidikan Nilai, Bandung: Alpabeta..

Narwanti, (2011). Pendidikan Karakter Pengintegrasian 18 Nilai Dalam Mata Pelajaran, Yogyakata: Familia.

Poedjiadi, A. (1999), Pengantar Filsafat Ilmu bagi Pendidik. Bandung: Yayasan Cendrawasih.

Poerwadarminta, W.J.S. (1976). Kamus Umum Bahasa Indonesia, Jakarta: Balai Pustaka.

Qowaid, dkk., (2007). Inovasi Pembelajaran PAI, Jakarta: Pena Citrasatria.

Russel, Stephen \& Rosalie J. Bakken, (2002). Development of Autonomy in Adolescence. University of Nebraska: NebGuide, G1449 (http://extension.unl.edu/publications)

Sizer, Theodore, (1992). Horace's School, New York : Houghton Mifflin.

Souders, John dan Carolyn Prescott, (1999). $A$ Case for Contextual Learning School in Middle.

Sumarmo, (2004). Kemandirian Belajar: Apa, Mengapa dan Bagaimana Dikembangkan pada Peserta Didik. Makalah disajikan pada Seminar Pendidikan Matematika di Jurusan Matematika FMIPA Universitas Negeri Yogyakarta, Tanggal 8 Juli 2004

Surya, Hendra, (2003). Kiat Mengajak Anak Belajar dan Berprestasi. Jakarta: PT. Grasindo.

Tasker, R. 1992. Effective Teaching: What Can a Constructivist View of Learning Offer. The Australian Science Teacher JouTyrnal.

Thoha, Chabib, (1996). Kapita Selekta Pendidikan Islam. Yogyakarta : Pustaka Pelajar IKAPI.

Tuloli, J.H., (1991). Transformasi Potensi Generasi Muda Menuju Insan Mandiri: Menguak Kegiatan Pembina 
Pramuka di Indonesia, Disertasi Doktor. Bandung : FPS-IKIP. Tidak diterbitkan.

Wheatley, G.H. 1991. Constructivist Perspective on Science and Mathematics Learning. Science Education Journal.

Zubaidi, (2010). Desain Pendidikan Karakter Konsepsi dan Aplikasinya dalam Lembaga Pendidikan, Jakarta: Pt. Rajagrafindo 